\section{Godt om cannabis og psykiatri}

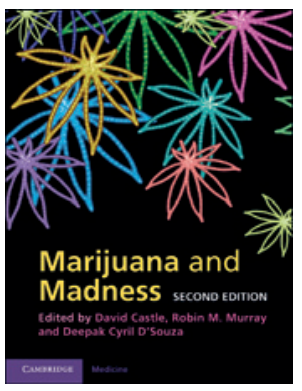

David Castle, Robin M. Murray,

Deepak Cyril D'Souza, red.

Marijuana and madness

2. utg. 240 s, tab., fig, ill. Cambridge:

Cambridge University Press, 2011.

Pris GBP 55

ISBN 978-1-107-00021-6

Siden førsteutgaven av denne medisinsk vinklede og godt redigerte boken kom i 2004 har den medisinske litteraturen om psykiske følger av cannabisbruk og om cannabinoiders nevrobiologi nesten doblet seg. Derfor er denne utgaven betydelig endret og utvidet. På en forbilledlig måte tar forfatterne oss fra intracellulære prosesser, via nevroanatomi, til kliniske funn og behandling og forebygging.

Vår utvidede forståelse av det endocannabinoide systemet er omtalt bredt både med henblikk på nevrobiologisk funksjon og hjernens utvikling. Dette danner et godt bakteppe for å belyse emner som cannabis' innvirkning på kognitive evner og mulige hjerneskader og om sammenhengen mellom cannabisbruk og depresjon og andre affektive lidelser. Til sist er det en grundig og lang omtale av sammenhengen mellom cannabisbruk og schizofreni. Selv om jeg hadde ønsket en enda bredere gjennomgang av alternative årsaksforklaringer til den observerte samvariasjonen mellom bruk av cannabis og schizofreni, så gjengir forfatterne de viktigste funnene på en god, om enn noe tradisjonell måte. De vinkler også stoffet på ulike måter og får gjennom dette frem mange nyanser.

Målgruppen er først og fremst de som kan mye om rus og psykiatri. Det kan være folk som jobber med dobbeltdiagnoseproblematikk, dvs. den interesserte kliniker, selv om boken inneholder få direkte kliniske råd. Men mest vil boken nok være til nytte for dem som involverer seg forskningsmessig på feltet. I mange forskeres øyne inneholder bøker ofte allerede gammel kunnskap, men her finnes betydningsfulle referanser helt frem 2011. Blant annet refereres de to viktigste norske bidragene på dette feltet $(1,2)$.

Boken er en av mange om cannabis, politikk og medisin. Jeg har tidligere anmeldt Cannabis policy: moving beyond stalemate (3). Mens den hadde et klart budskap om å forsøke å bilegge krigen mot narkotika, fremstår årets bok mer som en advarsel. Når noen av forfatterne skriver i begge bøkene, kan man kanskje spørre hva disse forfatterne egentlig mener. Men jeg oppfatter begge to som vitenskapelig redelige, hvor forskerne bidrar med sin kunnskap på en nokså verdinøytral måte.

Illustrasjonene er fine og passende, og stikkordregisteret er godt. Dette er altså en bok å anbefale den interesserte leser.

\section{Jørgen G. Bramness}

Senter for rus og avhengighetsforskning

Universitetet i Oslo

Litteratur

1. Ringen PA, Vaskinn A, Sundet K et al. Opposite relationships between cannabis use and neurocognitive functioning in bipolar disorder and schizophrenia. Psychol Med 2010; 40: 1337-47.

2. Løberg EM, Hugdahl K. Cannabis use and cognition in schizophrenia. Front Hum Neurosci 2009; 3: 53

3. Bramness JG. Godt dokumentert om cannabis og cannabispolitikk. Anmeldelse av: Room R, Fischer B, Hall W et al. Cannabis policy: moving beyond stalemate. Tidsskr Nor Legeforen 2010; 130: 1383

\section{Biomekanikk for idrettsstudenter}

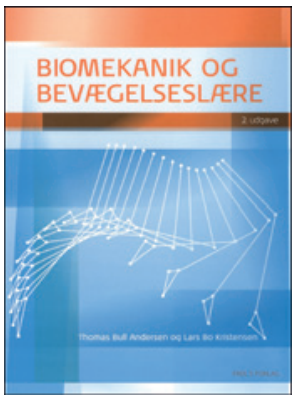

Thomas Bull Andersen, Lars Bo Kristensen Biomekanik og bevægelseslære

2. utg. 144 s, tab, ill. København: FADL's Forlag 2011. Pris DKK 330

ISBN 978-87-7749-611-0

Innsikt i biomekanikk er av betydning for leger i flere sammenhenger. Samtidig er det et felt som - hvis det skal beherskes ut over det elementære og intuitive - krever betydelige kunnskaper i fysikk og matematikk, ved siden av anatomi. Denne boken er ment som en introduksjon til biomekanikken, og er spesielt rettet mot studenter i idrett ved universitetene i Danmark. Matematiske termer som funksjoner og differensial- og vektorregning brukes gjennom hele teksten og forklares kortfattet på relevante steder.

Det er ti kapitler. De to første omhandler lineær kinematikk og kinetikk, dvs. bevegelser og hvordan de oppstår. Så følger kapitler om arbeid og energi, antropometri og angulær kinematikk og kinetikk. I kapittel 7-9 behandler forfatterne impulsteori, statikk og bevegelser i luft og vann. I siste kapittel omtaler de analysemetoder i biomekaniske undersøkelser, bl.a. EMG som er omtalt på under en halv side.

Forfatterne gir mange eksempler på bruk av biomekanikk på menneskekroppen i ro og i bevegelse, hele tiden med bruk av matematiske formler og begreper for anskueliggjøring og utregning. Et flertall av eksemplene er naturlig nok - tatt i betraktning målgruppen - fra idretten. Forfatterne sier selv at de har tatt med så mye av den grunnleggende mekanikken som er nødvendig for at studenter, uten høyeste nivå av fysikk og matematikk, skal kunne nyttiggjøre seg eksemplene. Men realiteten er nok at med en så sterkt matematisk dominert fremstilling må man ha betydelige forkunnskaper for å tilegne seg stoffet. Det holder neppe med de kortfattede innføringene som forfatterne gir underveis.

Alt $\mathrm{i}$ alt tror jeg ikke denne boken er spesielt egnet for medisinere som ønsker å bedre sin innsikt i biomekanikk.

\section{Per Brodal}

Institutt for medisinske basalfag

Universitetet i Oslo 